\title{
KANA PASSAMBE 'PRONOMINA' PADA TEKS CERITA RAKYAT MAKASSAR
}

\section{Riyatni Imas Garina}

Universitas Negeri Makassar (UNM) Sulawesi, Indonesia

Email: riyatniimasgarina@gmail.com

\section{Abstract}

This research is a qualitative research with an analysis of the functions and roles of kana passambe 'pronouns' in the text of Makassar folklore. The data used is written data. The written data is in the form of kana passambe which consists of kana passambe kale, panjojjok, and tampak which appears to be taken from a textbook of Makassar folk tales. Data collection techniques used in written data are documentation techniques, reading techniques and note taking techniques, then the data collected is analyzed descriptively qualitatively. The results of the data analysis show that: first, the function and role of kana passambe kale 'personal pronouns' which consist of the first, second, and third (singular and plural) personal pronouns in the Makassar folklore text found two functions, namely the function as object and subject along with three roles, namely the role of sufferer, actor, and receiver. Second, the function and role of kana passambe panjojjok 'pointer pronoun' in the Makassar folklore text found three functions, namely the function of the subject attribute, the function of the object attribute, and the function of description along with eight roles, namely the role of actor, experience, participant, tool, place, time, recipients, and sufferers. Third, the function and role of kana passambe tampak is seen as 'place pronoun' in the Makassar folklore text, where only one function is found, namely the function of information along with two roles, namely the role of place and existence.

Keywords: pronth word; makassar folklore

\section{Abstrak}

Penelitian ini termasuk penelitian kualitatif dengan analisis fungsi dan peran kana passambe 'pronomina' pada teks cerita rakyat Makassar. Data yang digunakan adalah data tertulis. Data tertulis berupa kana passambe yang terdiri atas kana passambe kale, panjojjok, dan tampak yang diambil dari buku teks cerita rakyat Makassar. Teknik pengumpulan data yang digunakan pada data tertulis berupa teknik dokumentasi, teknik baca dan teknik catat, kemudian data yang dikumpulkan dianalisis secara deskriptif kualitatif. Hasil analisis data menunjukkan bahwa: pertama, fungsi dan peran kana passambe kale 'pronomina persona' yang terdiri atas pronomina persona pertama, kedua, dan ketiga (tunggal dan jamak) pada teks cerita rakyat Makassar ditemukan dua fungsi, yakni fungsi sebagai objek dan subjek beserta tiga peran, yakni peran penderita, pelaku, dan penerima. Kedua, fungsi dan peran kana passambe panjojjok 'pronomina penunjuk' pada teks cerita rakyat Makassar ditemukan tiga fungsi, yakni fungsi atribut subjek, fungsi atribut objek, dan fungsi keterangan beserta delapan peran, yakni peran pelaku, pengalam,

$\begin{array}{ll}\text { How to cite: } & \text { Garina, Riyatni Imas (2021) Kana Passambe 'Pronomina’ pada Teks Cerita Rakyat Makassar, 3(6). } \\ & \text { https://doi.org/10.36418/syntax-idea.v3i6.1256 } \\ \text { E-ISSN: } & \text { 2684-883X } \\ \text { Published by: } & \text { Ridwan Institute }\end{array}$


peserta, alat, tempat, waktu, penerima, dan penderita. Ketiga, fungsi dan peran kana passambe tampak 'pronomina tempat' pada teks cerita rakyat Makassar hanya ditemukan satu fungsi, yakni fungsi keterangan beserta dua peran, yakni peran tempat dan keberadaan.

Kata Kunci: kana passambe; pronomina; cerita rakyat makassar

\section{Pendahuluan}

Secara garis besar, bahasa sebagai alat komunikasi bagi masyarakat. Melalui bahasa, masyarakat dapat saling berkomunikasi, berinteraksi, bekerja sama, dan mengidentifikasi diri (Pratama, 2017).

Bahasa merupakan salah satu ciri yang paling khas dan manusiawi untuk membedakan manusia dengan makhluk lainnya. Bahasa sebagai suatu sistem komunikasi adalah suatu bagian dari sistem kebudayaan, bahkan merupakan bagian inti kebudayaan. Bahasa juga terlibat dalam semua aspek kebudayaan (Devianty, 2017).

Pemerolehan bahasa merupakan bagian penting dari kehidupan seseorang. Bahasa merupakan alat komunikasi dan interaksi sosial yang harus dikuasai seseorang sejak dini (Salamah, 2015).

Bahasa memiliki arti yang penting dalam dunia politik. Bahasa menjadi media yang ampuh untuk menanamkan ideologi, merebut atau mendapatkan, serta mempertahankan kekuasaan (Asmara, 2016).

Setiap bahasa memiliki kaidah dan karakteristik tersendiri agar dapat dipahami dan digunakan dengan tepat. Salah satu hal penting yang harus diperhatikan dalam berbahasa adalah penggunaan pronomina atau kata ganti. Pronomina merupakan kata ganti yang berfungsi untuk menggantikan nomina. Pronomina dapat digunakan baik secara lisan maupun tertulis. Secara lisan, pronomina biasanya digunakan dalam percakapan sehari-hari sedangkan secara tertulis, penggunaan pronomina dapat dijumpai dalam berbagai macam teks atau wacana (Sarisati, 2017).

Bahasa daerah merupakan aset berharga suatu bangsa. Akan tetapi, paradigma masyarakat abad 21 menilai bahwa bahasa asing memiliki prestise lebih tinggi dibandingkan bahasa nasional dan bahasa daerah (Widianto, 2018).

Bahasa daerah merupakan salah satu aset kebudayaan nasional yang harus dilestarikan dan dikembangkan agar dapat menjalankan fungsinya di tengah-tengah masyarakat pendukung- nya. Salah satu penggunaan pronomina yang menarik dapat ditemukan dalam bahasa Makassar. Bahasa Makassar adalah salah satu bahasa daerah yang dituturkan oleh suku Makassar yang mendiami bagian selatan jazirah Sulawesi Selatan. Bahasa ini memiliki wilayah pemakaian terbesar kedua di Sulawesi Selatan setelah bahasa Bugis (Rachman, 2016).

Pronomina atau kata ganti dalam bahasa Makassar dikenal dengan istilah kana passambe. Berdasarkan kata yang digantikan, kana passambe dalam bahasa Makassar digolongkan menjadi tiga jenis. Penggolongan tersebut terdiri atas kana passambe kale 'pronomina persona', kana passambe panjojjok 'pronomina penunjuk', dan kana passambe tampak 'pronomina tempat'. 
Penggunaan kana passambe dalam bahasa Makassar salah satunya dapat ditemukan pada teks, dalam hal ini teks yang dimaksud adalah teks cerita rakyat. Cerita rakyat merupakan buah pikiran dari warisan leluhur yang mengandung banyak pesan. Sebagai bagian dari kebudayaan yang mengandung berbagai gagasan dan memiliki makna yang bermanfaat, cerita rakyat diwariskan secara turun-temurun dan menjadi milik masyarakat tempat cerita tersebut berasal. Apabila dikaji secara mendalam, cerita rakyat mengandung nilai-nilai moral yang dapat dijadikan pembelajaran dalam menjalankan kehidupan sehari-hari (Agustina, 2013).

Pada teks, setiap kata pada dasarnya memiliki acuan yang merujuk pada sesuatu yang berfungsi untuk menjelaskan, memberikan makna, ataupun menyatakan sesuatu dalam sebuah topik yang ingin disampaikan. Sebuah teks atau wacana akan selalu ditemukan penggunaan kata ganti. Hal ini disebabkan karena kata ganti memiliki fungsi untuk menerangkan kata sebelumnya dan guna menghindari kata yang berulang dalam sebuah kalimat ataupun paragraf. Berdasarkan uraian tersebut, cukup beralasan untuk dilakukan kajian yang lebih mendalam terkait kana passambe 'pronomina' pada teks cerita rakyat (Badara, 2014).

Beberapa judul penelitian terkait pronomina yang telah dilakukan oleh peneliti dari disiplin ilmu bahasa yang senada dengan penelitian ini antara lain penelitian yang dilakukan oleh (Cipta \& Arkanleema, 2013) dengan judul "Satuan Lingual yang Mengandung Pronomina Persona Kedua pada Teks Terjemahan Hadis pada Buku Sahih Buchori Muslim" yang menunjukkan hasil bahwa fungsi yang ditemukan oleh satuan lingual ber-PP2 meliputi fungsi subjek, predikat, objek, atribut subjek, dan keterangan serta peran yang diisi oleh satuan lingual ber-PP2 mengisi peran pelaku, pengalam, perbuatan, perbandingan, kesertaan, cara, dan waktu. Adapun persamaan dengan penelitian ini adalah sama-sama menganalisis tentang pronomina, sedangkan perbedaannya adalah penelitian ini berfokus pada teks terjemahan hadis pada buku sahih Buchori Muslim sedangkan penulis berfokus pada buku cerita rakyat bahasa Makassar karya Zainuddin Hakim.

Selanjutnya, penelitian yang dilakukan oleh Faizah tahun 2017dengan judul "Pola Penggunaan Satuan Lingual yang Mengandung Pronomina Persona Ketiga pada Teks Terjemahan Al-Quran dan Teks Terjemahan Hadis Riwayat Buchori-Muslim dilihat dari Kategori dan Fungsinya" mengungkap hasil bahwa pola perubahan kategori satuan lingual berpronomina persona ketiga pada TTA dan TTH sebagai berikut: (1) pola kategori nomina menjadi frasa verba ialah PP III + verba $=\mathrm{FV}$; (2) pola kategori nomina menjadi frasa preposisi ialah Preposisi + Nomina + PP 3 = F.Preposisi; (3) pola perubahan nomina menjadi frasa nomina jika $\mathrm{N}+\mathrm{PP} 3$ yang berfungsi subjek dan berperan pelaku atau pengalam; (4) pola nomina menjadi frasa atributif terjadi jika $\mathrm{F}$ (yang) + nomina ber-PP 3 + verba. Perbedaannya dengan penelitian yang dilakukan oleh penulis ialah penulis meneliti pronomina pada teks cerita rakyat sedangkan Faizah meneliti pronomina persona pada teks terjemahan Al-Quran dan dan teks terjemahan hadis. Kesamaan yang penulis lakukan dengan penelitian yang dilakukan oleh Faizah adalah sama-sama menelusuri pronominal (Badara, 2014). 
Penelitian lain juga dilakukan oleh (SW, 2019) dengan judul "Fungsi Pronomina Persona Pertama dalam Bahasa Sasak Dialek Menu-Meni” yang menemukan hasil bahwa pronomina persona dalam bahasa Sasak terdiri atas tiga persona, yakni pronomina persona pertama, pronomina persona kedua, dan pronomina persona ketiga. Ketiga jenis pronomina tersebut memiliki bentuk bebas dan bentuk terikat masingmasing serta memiliki bentuk tunggal dan bentuk jamak. Pronomina persona dalam bahasa Sasak dialek Menu-Meni ditemukan dapat mengalami perubahan bentuk dari bebas menjadi bentuk pronomina persona terikat. Dilihat dari fungsi sintaktis, pronomina persona dalam dialek Menu-Meni dapat menduduki fungsi sintaktis subjek, objek, dan keterangan. Dilihat dari fungsi semantis, pronomina persona bersifat sebagai pengacu anafora dan katafora. Yang terakhir dari segi letak dan pelekatan ditemukan bahwa pronomina persona bebas memiliki distribusi letak yang lebih banyak dibandingkan dengan pronomina persona bentuk terikat. Penelitian ini memiliki persamaan dan perbedaan. Persamaannya adalah sama-sama membahas tentang aspek pronomina, tetapi penulis meneliti pronomina pada teks cerita rakyat sedangkan perbedaannya adalah objek yang diteliti oleh Wahyuni yaitu bahasa Sasak sedangkan objek yang penulis teliti adalah tentang pronomina pada teks cerita rakyat bahasa Makassar.

Adapun penelitian relevan yang berkaitan dengan kana passambe 'pronomina' dalam bahasa Makassar sebelumnya telah dilakukan oleh (Daeng, 2016) yang dituliskan dalam bukunya yang berjudul Pappilajarang Basa Siagang Sasetera Mangkasarak Kalasak VII. Buku tersebut telah menyajikan tentang pronomina beserta jenis-jenis pronomina dalam bahasa Makassar

Setelah menjabarkan semua hasil penelitian relevan, yang berbeda dari penelitian sebelumnya dengan penelitian ini adalah pronomina yang dikaji merupakan kana passambe 'pronomina' dalam bahasa Makassar dilihat berdasarkan fungsi dan perannya pada teks cerita rakyat Makassar.

\section{Metode Penelitian}

Jenis penelitian ini adalah jenis penelitian kualitatif yang disajikan secara deskriptif dengan tujuan mengungkap kana passambe 'pronomina' (fungsi dan peran) pada teks cerita rakyat Makassar.

Penelitian ini merupakan penelitian yang menganalisis kana passambe 'pronomina' (fungsi dan peran) pada teks. Penelitian ini berobjek pada penggunaan kana passambe 'pronomina' pada teks cerita rakyat Makassar, sehingga dalam pelaksanaannya tidak terikat dengan tempat.

Penelitian ini difokuskan pada kana passambe 'pronomina' bahasa Makassar yang meliputi kana passambe kale 'pronomina persona', kana passambe panjokjok 'pronomina penunjuk', dan kana passambe tampak 'pronomina tempat' dengan menganalisis fungsi dan peran pada teks cerita rakyat Makassar.

Data yang digunakan dalam penelitian ini adalah data tertulis berupa kana passambe 'pronomina' yang terdiri atas kana passambe kale 'pronomina persona', kana passambe panjojjok 'pronomina penunjuk', dan kana passambe tampak 'pronomina 
tempat' yang terdapat pada teks cerita rakyat Makassar. Sementara sumber data yang digunakan dalam penelitian ini adalah buku karya Zainuddin Hakim yang berjudul Cerita Rakyat Makassar, yang terdiri dari 130 halaman dengan 16 judul cerita rakyat.

Untuk memperoleh data mengenai kana passambe 'pronomina' (fungsi dan peran) pada teks cerita rakyat Makassar, digunakan beberapa teknik pengumpulan data yang relevan dengan tujuan yang ingin dicapai. Teknik yang digunakan dalam penelitian ini adalah dokumentasi, baca, dan catat. Selanjutnya, pemeriksaaan keabsahan data dalam penelitian ini menggunakan teknik triangulasi lalu dianalisis menggunakan model analisis interaktif dengan tiga langkah analisis, yakni: reduksi data, sajian data, dan penarikan simpulan.

\section{Hasil dan Pembahasan}

1. Deskripsi Fungsi dan Peran Kana Passambe Kale 'Pronomina Persona' Hasil analisis fungsi dan peran kana passambe kale 'pronomina persona' pada teks cerita rakyat Makassar adalah sebagai berikut.

a. Fungsi dan Peran Pronomina Persona Pertama Tunggal: Nakke

Fungsi dan peran pronomina persona pertama tunggal pada teks cerita rakyat Makassar dapat ditunjukkan oleh data berikut:

1) “Apa erok kipalak kutaeng ri nakke daeng?” (cerita 1, paragraf 23)

'Apa gerangan yang kakak ingin minta dari saya?'

\begin{tabular}{cccccc}
\hline No. Data & \multicolumn{5}{c}{ Kalimat } \\
\hline$(1: 23) 3$ & Apa & Erok & Kipalak & Kutaeng ri nakke & Daeng \\
\hline $\mathrm{F}$ & - & $\mathrm{P}$ & $\mathrm{S}$ & $\mathrm{O}$ & Pel. \\
\hline $\mathrm{P}$ & - & Perbuatan & Pelaku & Penderita & Peserta \\
\hline
\end{tabular}

Berdasarkan analisis data di atas, dinyatakan bahwa nakke merupakan pronomina persona pertama tunggal yang mengisi fungsi objek dan peran penderita.

2) Appiwalimi angkana, "iyek, I nakke minne." (cerita 2, paragraf 10) 'Ia pun menjawab, "Ya, sayalah orangnya."

\begin{tabular}{ccc}
\hline No. Data & \multicolumn{2}{c}{ Kalimat } \\
\hline$(2: 10) 7$ & Appiwalimi angkana, iyek & Inakke minne \\
\hline $\mathrm{F}$ & $\mathrm{P}$ & $\mathrm{P}$ \\
\hline $\mathrm{P}$ & Perbuatan & Perbuatan \\
\hline
\end{tabular}

Berdasarkan analisis data di atas, dinyatakan bahwa nakke merupakan pronomina persona pertama tunggal yang mengisi fungsi subjek dan peran pelaku.

3) I nakke erok tongak ambalasaki. (cerita 7, paragraf 3)

'Saya juga ingin membalas dia.'

\begin{tabular}{ccc}
\hline No. Data & Kalimat \\
\hline$(7: 3) 23$ & I nakke & Erok tongkak ambalasak \\
\hline
\end{tabular}




\begin{tabular}{cccc}
\hline $\mathrm{F}$ & $\mathrm{S}$ & $\mathrm{P}$ & $\mathrm{O}$ \\
\hline $\mathrm{P}$ & Pelaku & Perbuatan & Penderita \\
\hline
\end{tabular}

Berdasarkan analisis data tersebut, dinyatakan bahwa nakke merupakan pronomina persona pertama tunggal yang mengisi fungsi subjek dan peran pelaku.

b. Fungsi dan Peran Pronomina Persona Kedua Tunggal Honorifik: Katte

Fungsi dan peran pronomina persona kedua tunggal honorifik pada teks cerita rakyat Makassar dapat ditunjukkan oleh data berikut:

4) I katte rupa taua tena niakka nakinnganre battu rawa, mingka anngapai nasimata lakbuangang bulu-bulunna ulua na bulu-bulunna bitisika. (cerita 16, paragraf 8)

'Kita umat manusia tidak pernah makan dari bawah, akan tetapi mengapa selalu rambut kepala lebih panjang daripada bulu-bulu betis.'

\begin{tabular}{ccccc}
\hline No. Data & \multicolumn{4}{c}{ Kalimat } \\
\hline (16:8) 2 & $\begin{array}{c}\text { I katte } \\
\text { rupataua }\end{array}$ & $\begin{array}{c}\text { Tena niakka } \\
\text { nakinnganre }\end{array}$ & $\begin{array}{c}\text { Batuu rawa mingka } \\
\text { anngapai nasimata } \\
\text { lakbuangang }\end{array}$ & $\begin{array}{c}\text { Bulu-bulunnaulua } \\
\text { na bulu-bulunna } \\
\text { bitisika }\end{array}$ \\
\hline $\mathrm{F}$ & $\mathrm{S}$ & $\mathrm{P}$ & Ket. & O \\
\hline $\mathrm{P}$ & Pelaku & Perbuatan & Sebab & Hasil \\
\hline
\end{tabular}

Berdasarkan analisis data di atas, dinyatakan bahwa katte merupakan pronomina persona kedua tunggal honorifik yang mengisi fungsi subjek dan peran pelaku.

c. Fungsi dan Peran Pronomina Persona Kedua Tunggal Familiar: Kau

Fungsi dan peran pronomina persona kedua tunggal familiar pada teks cerita rakyat Makassar dapat ditunjukkan oleh data berikut:

1) Appiwalimi ammakna angkana, "I kau anakku kaminang toaya la kusaremako paarengang." (cerita 1, paragraf 5)

'Menyahutlah ibunya, "Engkau anakku yang sulung, saya akan memberimu nama.'

\begin{tabular}{ccccc}
\hline No. Data & Appiwalimi & $\begin{array}{c}\text { Ammakna } \\
\text { angkana }\end{array}$ & $\begin{array}{c}\text { I kau } \\
\text { anakku }\end{array}$ & $\begin{array}{c}\text { Kaminang toaya la } \\
\text { kusaremako } \\
\text { paarengang }\end{array}$ \\
\hline (1:5) 15 & $\mathrm{P}$ & $\mathrm{S}$ & $\mathrm{O}$ & Ket. \\
\hline $\mathrm{P}$ & Perbuatan & Pelaku & Penerima & Pemerolehan \\
\hline
\end{tabular}

Berdasarkan analisis data di atas, dinyatakan bahwa kau merupakan pronomina persona kedua tunggal familiar yang mengisi fungsi objek dan peran penerima.

2) Akkanami ammakna angkana, "I kau toaya kuarengko Puttiri Lila Sari." (cerita 1, paragraf 5)

'Menjawablah ibunya, "Engkau yang sulung kuberi nama Putri Lila Sari."

\begin{tabular}{|c|c|}
\hline No. Data & Kalimat \\
\hline$(1: 5) 17$ & Akkanami \\
\hline
\end{tabular}




\begin{tabular}{|c|c|c|c|c|}
\hline & & angkana & & Lila Sari \\
\hline $\mathrm{F}$ & $\mathrm{P}$ & $\mathrm{S}$ & $\mathrm{O}$ & Ket. \\
\hline $\mathrm{P}$ & Perbuatan & Pelaku & Penerima & Hasil \\
\hline
\end{tabular}

Berdasarkan analisis data di atas, dinyatakan bahwa kau merupakan pronomina persona kedua tunggal familiar yang mengisi fungsi objek dan peran penerima.

3) Akkanami ammakna angkana, "I kau antu kuareng Puttiri Lamba Sari." (cerita 1, paragraf 5)

'Menjawablah ibunya, "Engkau kuberi nama Putri Lamba Sari."

\begin{tabular}{ccccc}
\hline No. Data & \multicolumn{3}{c}{ Kalimat } \\
\hline$(1: 5) 19$ & Akkanami & $\begin{array}{c}\text { ammakna } \\
\text { angkana }\end{array}$ & I kau antu & $\begin{array}{c}\text { Kuareng Puttiri } \\
\text { Lamba Sari }\end{array}$ \\
\hline $\mathrm{F}$ & $\mathrm{P}$ & $\mathrm{S}$ & $\mathrm{O}$ & Ket. \\
\hline $\mathrm{P}$ & Perbuatan & Pelaku & Penerima & Hasil \\
\hline
\end{tabular}

Berdasarkan analisis data tersebut, dinyatakan bahwa kau merupakan pronomina persona kedua tunggal familiar yang mengisi fungsi objek dan peran penerima.

4) Nakanamo ammakna, "I kaumi antu anak kuareng Puttiri Bida Sari." (cerita 1, paragraf 5)

'Menjawablah ibunya, "Engkaulah yang kuberi nama Putri Bida Sari."

\begin{tabular}{ccccc}
\hline No. Data & \multicolumn{4}{c}{ Kalimat } \\
\hline (1:5) 22 & Nakanamo & Ammakna & $\begin{array}{c}\text { I kau antu } \\
\text { anak }\end{array}$ & $\begin{array}{c}\text { Kuareng Puttiri } \\
\text { Bida Sari }\end{array}$ \\
\hline $\mathrm{F}$ & $\mathrm{P}$ & $\mathrm{S}$ & $\mathrm{O}$ & Ket. \\
\hline $\mathrm{P}$ & Perbuatan & Pelaku & Penerima & Hasil \\
\hline
\end{tabular}

Berdasarkan analisis data tersebut, dinyatakan bahwa kau merupakan pronomina persona kedua tunggal familiar yang mengisi fungsi objek dan peran penerima.

5) “I kau antu padanggang niaka atturungang ri bawana Gowa?" (cerita 2, paragraf 10)

"Engkaukah pedagang yang sementara berlabuh di muara Gowa?"

\begin{tabular}{cccc}
\hline No. Data & \multicolumn{3}{c}{ Kalimat } \\
\hline$(2: 10) 6$ & $\begin{array}{c}\text { I kau antu } \\
\text { padanggang }\end{array}$ & $\begin{array}{c}\text { Niaka } \\
\text { atturungang }\end{array}$ & $\begin{array}{c}\text { Ri bawana } \\
\text { Gowa }\end{array}$ \\
\hline $\mathrm{F}$ & $\mathrm{S}$ & $\mathrm{P}$ & Ket. \\
\hline $\mathrm{P}$ & Pelaku & Keadaan & Tempat \\
\hline
\end{tabular}

Berdasarkan analisis data di atas, dinyatakan bahwa kau merupakan pronomina persona kedua tunggal familiar yang mengisi fungsi subjek dan peran pelaku. 
6) Nakanamo Karaeng Sombaya, "anne asea sannging I kau patanna, niakpa lakbinnu nanggappa pajama baraka." (cerita 2, paragraf 14)

"Berkatalah Sombaya, "Padi ini adalah milikmu dan ambillah semuanya, nanti kalau ada sisamu barulah para pekerja itu mendapatkan bagian.”

\begin{tabular}{ccccc}
\hline No. Data & & \multicolumn{3}{c}{ Kalimat } \\
\hline$(2: 14) 3$ & Nakanamo & $\begin{array}{c}\text { Karaeng } \\
\text { Sombaya }\end{array}$ & $\begin{array}{c}\text { Anne asea } \\
\text { sannging I } \\
\text { kau } \\
\text { patanna }\end{array}$ & $\begin{array}{c}\text { Niakpa lakbinnu } \\
\text { nanggappa pajama } \\
\text { Baraka }\end{array}$ \\
\hline $\mathrm{F}$ & $\mathrm{P}$ & $\mathrm{S}$ & $\mathrm{O}$ & Ket. \\
\hline $\mathrm{P}$ & Perbuatan & Pelaku & Penerima & Pemerolehan \\
\hline
\end{tabular}

Berdasarkan analisis data di atas, dinyatakan bahwa kau merupakan pronomina persona kedua tunggal familiar yang mengisi fungsi objek dan peran penerima.

7) “Antu I kau erokko nasambeang bainennu sarikbattang toanu." (cerita 2, paragraf 19)

"Sebenarnya kakakmu itu berniat merampas istrimu."

\begin{tabular}{ccccc}
\hline No. Data & \multicolumn{4}{c}{ Kalimat } \\
\hline$(2: 19) 6$ & Antu I kau & $\begin{array}{c}\text { Erokko } \\
\text { nasambeang }\end{array}$ & Bainennu & $\begin{array}{c}\text { Sarikbattang } \\
\text { toanu }\end{array}$ \\
\hline $\mathrm{F}$ & $\mathrm{S}$ & $\mathrm{P}$ & $\mathrm{O}$ & Pel. \\
\hline $\mathrm{P}$ & Penderita & Perbuatan & Penerima & Pelaku \\
\hline
\end{tabular}

Berdasarkan analisis data di atas, dinyatakan bahwa kau merupakan pronomina persona kedua tunggal familiar yang mengisi fungsi subjek dan peran penderita.

8) Teako akkana-kanai, I kau tonji anne kupauang. (cerita 7, paragraf 2)

'Jangan sampaikan kepada saudaramu yang lain, hanya engkau saja yang kuberitahukan.'

\begin{tabular}{ccccc}
\hline No. Data & \multicolumn{4}{c}{ Kalimat } \\
\hline (7:2) 13 & $\begin{array}{c}\text { Teako } \\
\text { akkana- } \\
\text { kanai }\end{array}$ & $\begin{array}{c}\text { I kau tonji } \\
\text { anne }\end{array}$ & Ku & Pauang \\
\hline $\mathrm{F}$ & $\mathrm{P}$ & $\mathrm{S}$ & $\mathrm{O}$ & Pel. \\
\hline $\mathrm{P}$ & Perbuatan & Penderita & Pelaka & Peserta \\
\hline
\end{tabular}

Berdasarkan analisis data tersebut, dinyatakan bahwa kau merupakan pronomina persona kedua tunggal familiar yang mengisi fungsi subjek dan peran penderita.

a. Fungsi dan Peran Pronomina Persona Ketiga Tunggal: Ia

Fungsi dan peran pronomina persona ketiga tunggal pada teks cerita rakyat Makassar dapat ditunjukkan oleh data berikut:

1) Baklalo ammentemmi ia la naung anngallei cincinna. (cerita 5, paragraf 8) 
'Ketika ia berdiri hendak mengambil cincin itu.'

\begin{tabular}{ccccc}
\hline No. Data & \multicolumn{5}{c}{ Kalimat } \\
\hline$(5: 8) 5$ & $\begin{array}{c}\text { Baklalo } \\
\text { ammentemmi }\end{array}$ & Ia & $\begin{array}{c}\text { La naung } \\
\text { anngallei }\end{array}$ & Cincinnal \\
\hline $\mathrm{F}$ & $\mathrm{P}$ & $\mathrm{S}$ & Ket. & O \\
\hline $\mathrm{P}$ & Perbuatan & Pelaku & Pengalam & Alat \\
\hline
\end{tabular}

Berdasarkan analisis data di atas, dinyatakan bahwa ia merupakan pronomina persona ketiga tunggal yang mengisi fungsi subjek dan mengisi peran pelaku.

2) Niakmo sekre wattu naccarik-carita ia rua ri birinna binangaya. (cerita 11, paragraf 2)

'Pada suatu ketika kedua binatang itu sedang bercerita di tepi sungai.'

\begin{tabular}{ccccc}
\hline No. Data & \multicolumn{5}{c}{ Kalimat } \\
\hline$(11: 2) 1$ & $\begin{array}{c}\text { Niakmo } \\
\text { sekre wattu }\end{array}$ & $\begin{array}{c}\text { Naccarik- } \\
\text { carita }\end{array}$ & Ia rua & $\begin{array}{c}\text { Ri birinna } \\
\text { binangaya }\end{array}$ \\
\hline $\mathrm{F}$ & Ket. & $\mathrm{P}$ & $\mathrm{S}$ & Ket. \\
\hline $\mathrm{P}$ & Waktu & Perbuatan & Pelaku & Tempat \\
\hline
\end{tabular}

Berdasarkan analisis data tersebut, dinyatakan bahwa ia merupakan pronomina persona ketiga tunggal yang mengisi fungsi subjek dan mengisi peran pelaku.

3) Apaji na nitarimami ia, battuang kana niangkakmi akjari julu tulisikna karaenga. (cerita 12, paragraf 11)

'Akhirnya ia diterima menjadi juru tulis raja.'

\begin{tabular}{ccccc}
\hline No. Data & \multicolumn{4}{c}{ Kalimat } \\
\hline$(12: 11) 9$ & $\begin{array}{c}\text { Apaji na } \\
\text { nitarimami }\end{array}$ & ia & $\begin{array}{c}\text { Battuang kana } \\
\text { niangkakmi akjari } \\
\text { julu tulisikna }\end{array}$ & Karaenga \\
\hline $\mathrm{F}$ & $\mathrm{P}$ & $\mathrm{S}$ & Ket. & $\mathrm{O}$ \\
\hline $\mathrm{P}$ & Hasil & Penerima & Pengalam & Pelaku \\
\hline
\end{tabular}

Berdasarkan analisis data di atas, dinyatakan bahwa ia merupakan pronomina persona ketiga tunggal yang mengisi fungsi subjek dan mengisi peran penerima.

4) Niakmo sekre wattu nakbicak-bicara ia rua ri wattu ammotereknamo mange ri ballakna ri labunamo matanna alloa. (cerita 13, paragraf 1)

'Pada suatu hari mereka berdua berbincang-bincang, tatkala mereka kembali ke rumah pada sore harinya. 
Riyatni Imas Garina

\begin{tabular}{ccccc}
\hline No. Data & \multicolumn{4}{c}{ Kalimat } \\
\hline$(13: 1) 4$ & $\begin{array}{c}\text { Niakmo } \\
\text { sekrewattu }\end{array}$ & $\begin{array}{c}\text { Nakbicak- } \\
\text { bicara }\end{array}$ & Ia rua & $\begin{array}{c}\text { Ri wattu } \\
\text { ammotereknamo mange } \\
\text { ri ballakna ri labunamo } \\
\text { matanna alloa }\end{array}$ \\
\hline $\mathrm{F}$ & Ket. & $\mathrm{P}$ & $\mathrm{S}$ & Ket. \\
\hline $\mathrm{P}$ & Waktu & Perbuatan & Pelaku & Tempat \\
\hline
\end{tabular}

Berdasarkan analisis data tersebut, dinyatakan bahwa ia merupakan pronomina persona ketiga tunggal yang mengisi fungsi subjek dan mengisi peran pelaku.

\section{Deskripsi Fungsi dan Peran Kana Passambe Panjojjok 'Pronomina Penunjuk'}

Hasil analisis fungsi dan peran kana passambe panjojjok 'pronomina penunjuk' pada teks cerita rakyat Makassar adalah sebagai berikut.

a. Fungsi dan Peran Pronomina Penunjuk: Anne

Fungsi dan peran pronomina penunjuk anne pada teks cerita rakyat Makassar dapat ditunjukkan oleh data berikut:

1) Anne tedong niaka annganrei rukuk i lalang ri romanga. (cerita 1, paragraf 3)

'Kerbau ini sementara makan rumput di dalam hutan.'

\begin{tabular}{ccccc}
\hline No. Data & \multicolumn{5}{c}{ Kalimat } \\
\hline (1:3) 1 & $\begin{array}{c}\text { Anne } \\
\text { tedong }\end{array}$ & $\begin{array}{c}\text { Niaka } \\
\text { anggganrei }\end{array}$ & Rukuk & $\begin{array}{c}\text { I Lalang ri } \\
\text { romanga }\end{array}$ \\
\hline $\mathrm{F}$ & $\mathrm{S}$ & $\mathrm{P}$ & $\mathrm{O}$ & ket. \\
\hline $\mathrm{P}$ & Pelaku & Perbuatan & Penderita & Tempat \\
\hline
\end{tabular}

Berdasarkan analisis data tersebut, dinyatakan bahwa anne merupakan pronomina penunjuk yang menunjang fungsi subjek dan mengisi peran pelaku.

2) Nakanamo anne anak karaeng tallua, "niak anakna Pung Tedong". (cerita 1, paragraf 10)

'Berkatalah ketiga putra raja ini, "Rupanya kerbau itu mempunyai anak.'

\begin{tabular}{ccccc}
\hline No. Data & \multicolumn{4}{c}{ Kalimat } \\
\hline$(1: 10) 12$ & Nakanamo & $\begin{array}{c}\text { Anne anak } \\
\text { karaeng } \\
\text { tallua }\end{array}$ & $\begin{array}{c}\text { Niak } \\
\text { anakna }\end{array}$ & Pung tedong \\
\hline $\mathrm{F}$ & $\mathrm{P}$ & $\mathrm{S}$ & $\mathrm{O}$ & Pel. \\
\hline $\mathrm{P}$ & Perbuatan & Peluka & Penderita & Peserta \\
\hline
\end{tabular}

Berdasarkan analisis data di atas, dinyatakan bahwa anne merupakan pronomina penunjuk yang menunjang fungsi subjek dan mengisi peran pelaku.

3) Naatorokmi anne anak karaeng tallua. (cerita 1, paragraf 10)

'Demikianlah cara ketiga putra raja ini mengaturnya.'

\begin{tabular}{llcl}
\hline No. Data & \multicolumn{3}{c}{ Kalimat } \\
\hline$(1: 10) 25$ & Naatorokmi & Anne anak & Tallua \\
\hline
\end{tabular}




\begin{tabular}{cccc}
\hline \multicolumn{4}{c}{ karaeng } \\
\hline $\mathrm{F}$ & $\mathrm{P}$ & $\mathrm{S}$ & Pel. \\
\hline $\mathrm{P}$ & Perbuatan & Peluka & Jumlah \\
\hline
\end{tabular}

Berdasarkan analisis data di atas, dinyatakan bahwa anne merupakan pronomina penunjuk yang menunjang fungsi subjek dan mengisi peran pelaku.

4) Anne padangganga akrupa-rupai nadanggangang, kammayami: sissik, bulaeng, siagang berasak. (cerita 2, paragraf 1)

'Pedagang ini menjual bermacam-macam barang dagangan, seperti: sisik, emas, dan beras.'

\begin{tabular}{cccc}
\hline No. Data & \multicolumn{3}{c}{ Kalimat } \\
\hline (2:1) 1 & $\begin{array}{c}\text { Anne } \\
\text { padangganga }\end{array}$ & $\begin{array}{c}\text { Akrupa-rupai } \\
\text { nadanggangang }\end{array}$ & $\begin{array}{c}\text { Kammayami: sisik, } \\
\text { bulaeng, siagang } \\
\text { berasak }\end{array}$ \\
\hline $\mathrm{F}$ & $\mathrm{S}$ & $\mathrm{P}$ & Ket. \\
\hline $\mathrm{P}$ & Pelaku & Perbuatan & Alat \\
\hline
\end{tabular}

Berdasarkan analisis data di atas, dinyatakan bahwa anne merupakan pronomina penunjuk yang menunjang fungsi subjek dan mengisi peran pelaku.

5) Lussakmi anne I Samindara Baine i rate ri ballaka. (cerita 4, paragraf 7)

'Gelisahlah Samindara Baine ini di atas rumah.'

\begin{tabular}{cccc}
\hline No. Data & \multicolumn{3}{c}{ Kalimat } \\
\hline (4:7) 10 & Lussakmi & $\begin{array}{c}\text { Anne I } \\
\text { samindara baine }\end{array}$ & $\begin{array}{c}\text { I rate ri } \\
\text { ballaka }\end{array}$ \\
\hline $\mathrm{F}$ & $\mathrm{P}$ & $\mathrm{S}$ & Ket. \\
\hline $\mathrm{P}$ & Keadaan & Pengalam & Tempat \\
\hline
\end{tabular}

Berdasarkan analisis data di atas, dinyatakan bahwa anne merupakan pronomina penunjuk yang menunjang fungsi subjek dan mengisi peran pengalam.

6) Anne I Samindara Baine amminawang tongi ri boko. (cerita 4, paragraf 9)

'I Samindara Baine ini mengikut dari belakang.'

\begin{tabular}{cccc}
\hline No. Data & \multicolumn{3}{c}{ Kalimat } \\
\hline (4:9) 8 & $\begin{array}{c}\text { Anne I } \\
\text { samindara } \\
\text { baine }\end{array}$ & Amminawang tongi & Ri boko \\
\hline $\mathrm{F}$ & $\mathrm{S}$ & $\mathrm{P}$ & Ket. \\
\hline $\mathrm{P}$ & Pelaku & Perbuatan & Tempat \\
\hline
\end{tabular}

Berdasarkan analisis data di atas, dinyatakan bahwa 'anne' merupakan pronomina penunjuk yang menunjang fungsi subjek dan mengisi peran pelaku.

7) Na anne karaenga tuli naparipakmaiki bainenna I Baso. (cerita 5, paragraf 3)

'Akan tetapi raja ini selalu menaruh hati kepada istri I Baso.' 


\begin{tabular}{ccccc}
\hline No. Data & \multicolumn{5}{c}{ Kalimat } \\
\hline (5:3) 9 & $\begin{array}{c}\text { Na anne } \\
\text { karaeng }\end{array}$ & $\begin{array}{c}\text { Tuli } \\
\text { naparipakmaiki }\end{array}$ & Bainenna & I Baso \\
\hline $\mathrm{F}$ & $\mathrm{S}$ & $\mathrm{P}$ & $\mathrm{O}$ & Pel. \\
\hline $\mathrm{P}$ & Pelaku & Perbuatan & Penderita & Peserta
\end{tabular}

Berdasarkan analisis data di atas, dinyatakan bahwa anne merupakan pronomina penunjuk yang menunjang fungsi subjek dan mengisi peran pelaku.

8) Na anne I Baso lintakmi ammoterek ri ballakna na napauang bainenna. (cerita 5, paragraf 4)

'Setelah ini, pulanglah I Baso ke rumahnya kemudian hal itu disampaikannya kepada istrinya.'

\begin{tabular}{ccccc}
\hline No. Data & \multicolumn{4}{c}{ Kalimat } \\
\hline$(5: 4) 6$ & $\begin{array}{c}\text { Na anne I } \\
\text { Baso }\end{array}$ & $\begin{array}{c}\text { Lintakmi } \\
\text { ammoterek }\end{array}$ & Ri ballakna & $\begin{array}{c}\text { Na } \\
\text { napauang } \\
\text { bainenna }\end{array}$ \\
\hline $\mathrm{F}$ & $\mathrm{S}$ & $\mathrm{P}$ & Ket. & $\mathrm{O}$ \\
\hline $\mathrm{P}$ & Pelaku & Perbuatan & Tempat & Penerima \\
\hline
\end{tabular}

Berdasarkan analisis data di atas, dinyatakan bahwa anne merupakan pronomina penunjuk yang menunjang fungsi subjek dan mengisi peran pelaku.

9) Kipinawang tongi sedeng anne pattujungku. (cerita 5, paragraf 4)

'Aku harap kakanda sudi mengikuti keinginanku ini.'

\begin{tabular}{cccc}
\hline No. Data & \multicolumn{3}{c}{ Kalimat } \\
\hline$(5: 4) 8$ & $K i$ & Pinawang tongi & $\begin{array}{c}\text { Anne } \\
\text { pattujungku }\end{array}$ \\
\hline $\mathrm{F}$ & $\mathrm{S}$ & $\mathrm{P}$ & $\mathrm{O}$ \\
\hline $\mathrm{P}$ & Pengalam & Perbuatan & Peserta \\
\hline
\end{tabular}

Berdasarkan analisis data di atas, dinyatakan bahwa anne merupakan pronomina penunjuk yang menunjang fungsi objek dan mengisi peran peserta.

10) Na anne karaenga natayammi Tuang Kadi kabattuanna anngerang kabarak ka singarakmi alloa. (cerita 5, paragraf 7)

'Sang raja ini sudah gelisah menunggu kedatangan Tuan Kadi membawa berita karena hari sudah terang.

\begin{tabular}{ccccc}
\hline No. Data & \multicolumn{4}{c}{ Kalimat } \\
\hline (5:7) 12 & $\begin{array}{c}\text { Na anne } \\
\text { karaenga }\end{array}$ & Natayammi & Tuang kadi & $\begin{array}{c}\text { Kabattuanna } \\
\text { anngerang kabarak } \\
\text { ka singarakmialoa }\end{array}$ \\
\hline $\mathrm{F}$ & $\mathrm{S}$ & $\mathrm{P}$ & $\mathrm{O}$ & Ket. \\
\hline $\mathrm{P}$ & Pelaku & Perbuatan & Penderita & Waktu \\
\hline
\end{tabular}

Berdasarkan analisis data di atas, dinyatakan bahwa anne merupakan pronomina penunjuk yang menunjang fungsi subjek dan mengisi peran pelaku.

11) Anne lapong tau toa mange ammalli gumbang batu. (cerita 7, paragraf 2)

'Pergilah orang tua ini membeli gumbang.' 


\begin{tabular}{cccc}
\hline No. Data & \multicolumn{3}{c}{ Kalimat } \\
\hline (7:2) 3 & $\begin{array}{c}\text { anne lapong } \\
\text { tau toa }\end{array}$ & Mange ammalli & $\begin{array}{c}\text { Gumbang } \\
\text { batu }\end{array}$ \\
\hline $\mathrm{F}$ & $\mathrm{S}$ & $\mathrm{P}$ & $\mathrm{O}$ \\
\hline $\mathrm{P}$ & Pelaku & Perbuatan & Alat \\
\hline
\end{tabular}

Berdasarkan analisis data tersebut, dinyatakan bahwa anne merupakan pronomina penunjuk yang menunjang fungsi subjek dan mengisi peran pelaku.

12) Jari, anne patti kupisanga doek bonena la kupaballi panngassengang. (cerita 12, paragraf 2)

'Jadi, peti yang saya bawa ini berisi uang, hendak kutukar dengan ilmu pengetahuan.'

\begin{tabular}{cccccc}
\hline No. Data & \multicolumn{5}{c}{ Kalimat } \\
\hline$(12: 2) 10$ & $\begin{array}{c}\text { Jari, anne } \\
\text { patti }\end{array}$ & $\mathrm{Ku}$ & pisanga & Doek bonena & $\begin{array}{c}\text { La kupaballi } \\
\text { panngassengang }\end{array}$ \\
\hline $\mathrm{F}$ & $\mathrm{O}$ & $\mathrm{S}$ & $\mathrm{P}$ & Pel. & Ket. \\
\hline $\mathrm{P}$ & Alat & Pelaku & Perbuatan & Alat & Pemerolehan \\
\hline
\end{tabular}

Berdasarkan analisis data di atas, dinyatakan bahwa anne merupakan pronomina penunjuk yang menunjang fungsi objek dan mengisi peran alat.

13) Nakanamo lapong Pesok, "bajikang punna anne bulaenga nierangi ammoterek ri pakrasanganta sikira-kira akkullea todong nierang. (cerita 13, paragraf 12)

'Berkatalah si Lumpuh, "baiklah kita bawa emas-emas ini semampu yang kita bawa.'

\begin{tabular}{ccccc}
\hline No. Data & \multicolumn{4}{c}{ Kalimat } \\
\hline$(13: 12) 1$ & Nakanamo & Lapong pesok & $\begin{array}{c}\text { Bajikangpunna } \\
\text { anne bulaenga }\end{array}$ & $\begin{array}{c}\text { Nierangi ammoterek } \\
\text { ripakrasanganta sikira- } \\
\text { kira akkullea todong } \\
\text { nierang }\end{array}$ \\
\hline $\mathrm{F}$ & $\mathrm{P}$ & $\mathrm{S}$ & $\mathrm{O}$ & Ket. \\
\hline $\mathrm{P}$ & Perbuatan & Pelaku & Alat & Tempat \\
\hline
\end{tabular}

Berdasarkan analisis data tersebut, dinyatakan bahwa anne merupakan pronomina penunjuk yang menunjang fungsi objek dan mengisi peran alat.

b. Fungsi dan Peran Pronomina Penunjuk: Anjo

Fungsi dan peran pronomina penunjuk anjo pada teks cerita rakyat Makassar dapat ditunjukkan oleh data berikut:

1) I lalanna anjo romanga niak todong sikayu tedong annganre rukuk. (cerita 1 , paragraf 1)

'Adapun kerbau yang sementara makan rumput di dalam hutan itu.'

\begin{tabular}{ccccc}
\hline No. Data & \multicolumn{4}{c}{ Kalimat } \\
\hline$(1: 1) 2$ & $\begin{array}{c}\text { I lalanna } \\
\text { anjo } \\
\text { romanga }\end{array}$ & $\begin{array}{c}\text { Niak todong } \\
\text { siyaku tedong }\end{array}$ & Angganre & Rukuk \\
\hline $\mathrm{F}$ & Ket. & $\mathrm{S}$ & $\mathrm{P}$ & $\mathrm{O}$ \\
\hline $\mathrm{P}$ & Tempat & Pelaku & Perbuatan & Penderita \\
\hline
\end{tabular}


Berdasarkan analisis data di atas, dinyatakan bahwa anjo merupakan pronomina penunjuk yang menunjang fungsi keterangan dan mengisi peran tempat.

2) Ri rampikna anjo romanga niak todong sekre karaeng ammantang. (cerita 1, paragraf 2)

'Di dekat hutan itu tinggal pula seorang raja.'

\begin{tabular}{cccc}
\hline No. Data & \multicolumn{3}{c}{ Kalimat } \\
\hline$(1: 2) 2$ & $\begin{array}{c}\text { Ri rampikna } \\
\text { anjo } \\
\text { romanga }\end{array}$ & $\begin{array}{c}\text { niak todong } \\
\text { sekre karaeng }\end{array}$ & ammantang \\
\hline $\mathrm{F}$ & Ket. & $\mathrm{S}$ & $\mathrm{P}$ \\
\hline $\mathrm{P}$ & Tempat & Pelaku & Perbuatan \\
\hline
\end{tabular}

Berdasarkan analisis data tersebut, dinyatakan bahwa anjo merupakan pronomina penunjuk yang menunjang fungsi keterangan dan mengisi peran tempat.

3) Anjo karaenga niak tallu anakna sannging burakne. (cerita 1, paragraf 2)

'Raja itu mempunyai tiga orang anak, semuanya laki-laki.'

\begin{tabular}{cccc}
\hline No. Data & \multicolumn{3}{c}{ Kalimat } \\
\hline$(1: 2) 2$ & $\begin{array}{c}\text { Anjo } \\
\text { karaenga }\end{array}$ & $\begin{array}{c}\text { Niak tallu } \\
\text { anakna }\end{array}$ & $\begin{array}{c}\text { Sannging } \\
\text { burakne }\end{array}$ \\
\hline $\mathrm{F}$ & $\mathrm{S}$ & $\mathrm{O}$ & Ket. \\
\hline $\mathrm{P}$ & Pelaku & Terjumlah & Pengenal \\
\hline
\end{tabular}

Berdasarkan analisis data di atas, dinyatakan bahwa anjo merupakan pronomina penunjuk yang menunjang fungsi subjek dan mengisi peran pelaku.

4) Na anjo anak karaeng tallua sisarikbattang ammempo-mempoi accokko ri bokona ballakna anakna Pung Tedong. (cerita 1, paragraf 10)

'Ketiga putra raja itu sedang duduk-duduk sambil bersembunyi di belakang rumah putri kerbau.'

\begin{tabular}{ccccc}
\hline No. Data & \multicolumn{4}{c}{ Kalimat } \\
\hline (1:10) 8 & $\begin{array}{c}\text { NaAnjo anak } \\
\text { karaeng tallua } \\
\text { sisarikbattang }\end{array}$ & $\begin{array}{c}\text { Ammempo- } \\
\text { mempoiaccokko }\end{array}$ & $\begin{array}{c}\text { Ri bokona } \\
\text { ballakna }\end{array}$ & $\begin{array}{c}\text { Anaknapung } \\
\text { tedong }\end{array}$ \\
\hline $\mathrm{F}$ & $\mathrm{S}$ & $\mathrm{P}$ & Ket. & O \\
\hline $\mathrm{P}$ & Pelaku & Perbuatan & Tempat & Penderita \\
\hline
\end{tabular}

Berdasarkan analisis data di atas, dinyatakan bahwa anjo merupakan pronomina penunjuk yang menunjang fungsi subjek dan mengisi peran pelaku.

5) Apaji nalarimo anjo Pung Tedong, ammakna I Puttiri Lila Sari. (cerita 1, paragraf 17)

'Kerbau itu pun berlari, ibu Si Putri Lila Sari.' 


\begin{tabular}{cccc}
\hline No. Data & \multicolumn{3}{c}{ Kalimat } \\
\hline$(1: 17) 1$ & Apajinalarimo & $\begin{array}{c}\text { Anjo pung } \\
\text { tedong, } \\
\text { ammakna }\end{array}$ & $\begin{array}{c}\text { I Puttiri Lila } \\
\text { Sari }\end{array}$ \\
\hline $\mathrm{F}$ & $\mathrm{P}$ & $\mathrm{S}$ & $\mathrm{O}$ \\
\hline $\mathrm{P}$ & Perbuatan & Pelaku & Penderita \\
\hline
\end{tabular}

Berdasarkan analisis data di atas, dinyatakan bahwa anjo merupakan pronomina penunjuk yang menunjang fungsi subjek dan mengisi peran pelaku.

6) Anjo wattua manna ballak takkekbuk ngaseng. (cerita 2, paragraf 1)

'Saat itu semua pintu rumah tertutup rapat.'

\begin{tabular}{cccc}
\hline No. Data & \multicolumn{3}{c}{ Kalimat } \\
\hline$(2: 1) 7$ & Anjo wattua & Manna ballak & $\begin{array}{c}\text { Takkekbuk } \\
\text { ngaseng }\end{array}$ \\
\hline $\mathrm{F}$ & Ket. & $\mathrm{S}$ & $\mathrm{P}$ \\
\hline $\mathrm{P}$ & Waktu & Tempat & Keadaan \\
\hline
\end{tabular}

Berdasarkan analisis data di atas, dinyatakan bahwa anjo merupakan pronomina penunjuk yang menunjang fungsi keterangan dan mengisi peran waktu.

7) Nakanamo anjo taua, "asea ri Lonjok Boko garringi." (cerita 2, paragraf 2)

"Menyahutlah orang itu, "Karena padi di Lonjok Boko rusak."

\begin{tabular}{cccccc}
\hline No. Data & \multicolumn{5}{c}{ Kalimat } \\
\hline$(2: 2) 4$ & Nakanamo & Anjo taua & Asea & $\begin{array}{c}\text { Ri lonjok } \\
\text { boko }\end{array}$ & Garringi \\
\hline $\mathrm{F}$ & $\mathrm{P}$ & $\mathrm{S}$ & $\mathrm{O}$ & Ket. & Pel. \\
\hline $\mathrm{P}$ & Perbuatan & Pelaku & Penderita & Tempat & Keadaan \\
\hline
\end{tabular}

Berdasarkan analisis data tersebut, dinyatakan bahwa anjo merupakan pronomina penunjuk yang menunjang fungsi subjek dan mengisi peran pelaku.

8) Anjo Adang Daeng Makleok sikali nabukubuk kabusuki selekna. (cerita 2, paragraf 23)

'Adapun Adam Daeng Makleok itu langsung melepaskan atau mencabut seluruh kerisnya dari sarungnya.'

\begin{tabular}{cccc}
\hline No. Data & \multicolumn{3}{c}{ Kalimat } \\
\hline$(2: 23) 1$ & $\begin{array}{c}\text { Anjo adang daeng } \\
\text { makleok }\end{array}$ & $\begin{array}{c}\text { Sikali nabukbuk } \\
\text { kabusuki }\end{array}$ & Selekna \\
\hline $\mathrm{F}$ & $\mathrm{P}$ & $\mathrm{S}$ & $\mathrm{O}$ \\
\hline $\mathrm{P}$ & Perbuatan & Pelaku & Penderita \\
\hline
\end{tabular}


Berdasarkan analisis data di atas, dinyatakan bahwa anjo merupakan pronomina penunjuk yang menunjang fungsi subjek dan mengisi peran pelaku.

9) Na anjo lapong tukalumannyang niak anakna sitau burakne nikana I Makuraga. (cerita 3, paragraf 2)

'Orang kaya itu mempunyai seorang anak laki-laki yang diberi nama I Makuraga.'

\begin{tabular}{ccccc}
\hline No. Data & \multicolumn{5}{c}{ Kalimat } \\
\hline$(3: 2) 1$ & $\begin{array}{c}\text { Na anjo lapong } \\
\text { tukalumannyang }\end{array}$ & Niak & anakna & $\begin{array}{c}\text { Sitau burakne nikana I } \\
\text { makuraga }\end{array}$ \\
\hline $\mathrm{F}$ & $\mathrm{S}$ & $\mathrm{P}$ & $\mathrm{O}$ & Ket. \\
\hline $\mathrm{P}$ & Pelaku & Keadaan & Pengalam & Pengenal \\
\hline
\end{tabular}

Berdasarkan analisis data di atas, dinyatakan bahwa anjo merupakan pronomina penunjuk yang menunjang fungsi subjek dan mengisi peran pelaku.

10) Na anjo bainenna akkoko tonji. (cerita 3, paragraf 2)

'Adapun istrinya itu hanya bekerja di kebun.'

\begin{tabular}{cccc}
\hline No. Data & \multicolumn{2}{c}{ Kalimat } & \\
\hline$(3: 2) 10$ & Na anjo baine & $N a$ & $\begin{array}{c}\text { Akkoko } \\
\text { tonji }\end{array}$ \\
\hline $\mathrm{F}$ & $\mathrm{S}$ & $\mathrm{O}$ & $\mathrm{P}$ \\
\hline $\mathrm{P}$ & Pengalam & Peserta & Keadaan \\
\hline
\end{tabular}

Berdasarkan analisis data di atas, dinyatakan bahwa anjo merupakan pronomina penunjuk yang menunjang fungsi subjek dan mengisi peran pengalam.

11) Anjo karaenga niak anakna sitau burakne. (cerita 4, paragraf 1)

'Raja itu mempunyai seorang anak laki-laki.'

\begin{tabular}{ccccc}
\hline No. Data & \multicolumn{5}{c}{ Kalimat } \\
\hline$(4: 1) 2$ & Anjo karaenga & Niak & anakna & Sitau burakne \\
\hline $\mathrm{F}$ & $\mathrm{S}$ & $\mathrm{P}$ & $\mathrm{O}$ & Ket. \\
\hline $\mathrm{P}$ & Pelaku & Keadaan & Pengalam & Pengenal \\
\hline
\end{tabular}

Berdasarkan analisis data di atas, dinyatakan bahwa anjo merupakan pronomina penunjuk yang menunjang fungsi subjek dan mengisi peran pelaku.

12) Anjo anakna niarengi nikana I Taruk Mallintotokeng. (cerita 4, paragraf 1)

'Anak itu diberi nama I Taruk Mallintotokeng.'

\begin{tabular}{ccccc}
\hline No. Data & \multicolumn{5}{c}{ Kalimat } \\
\hline$(4: 1) 3$ & Anjo anak & Na & $\begin{array}{c}\text { Niarengi } \\
\text { nikana }\end{array}$ & $\begin{array}{c}\text { I taruk } \\
\text { mallintotokeng }\end{array}$ \\
\hline $\mathrm{F}$ & $\mathrm{S}$ & $\mathrm{O}$ & $\mathrm{p}$ & Ket. \\
\hline $\mathrm{P}$ & Penerima & Pelaku & Perbuatan & Pengenal \\
\hline
\end{tabular}


Berdasarkan analisis data di atas, dinyatakan bahwa anjo merupakan pronomina penunjuk yang menunjang fungsi subjek dan mengisi peran penerima.

13) Anjo anak bainea nikana iareka naarengi I Samindara Baine. (cerita 4, paragraf 1)

'Anak perempuan itu diberi nama I Samindara Baine.'

\begin{tabular}{ccccc}
\hline No. Data & \multicolumn{4}{c}{ Kalimat } \\
\hline$(4: 1) 5$ & Anjo anak bainea & Nikanaiareka & $N a$ & $\begin{array}{c}\text { Arengi I } \\
\text { samindara baine }\end{array}$ \\
\hline $\mathrm{F}$ & $\mathrm{S}$ & $\mathrm{P}$ & $\mathrm{O}$ & Ket. \\
\hline $\mathrm{P}$ & Penerima & Perbuatan & Pelaku & Pengenal \\
\hline
\end{tabular}

Berdasarkan analisis data di atas, dinyatakan bahwa anjo merupakan pronomina penunjuk yang menunjang fungsi subjek dan mengisi peran penerima.

14) Apaji na naallemo I Baso anjo kurungang tallumbatua naerang ammoterek mange ri ballakna. (cerita 5, paragraf 5)

'Diambillah ketiga buah kurungan besi itu lalu dibawanya pulang ke rumahnya.'

\begin{tabular}{ccccc}
\hline No Data & \multicolumn{3}{c}{ Kalimat } \\
\hline (5:) 8 & $\begin{array}{c}\text { Apaji na } \\
\text { naallemo }\end{array}$ & I Baso & Anjo kurungana & $\begin{array}{c}\text { Naerang } \\
\text { ammoterek } \\
\text { Mange ri ballakna }\end{array}$ \\
\hline $\mathrm{F}$ & $\mathrm{P}$ & $\mathrm{S}$ & Tallumbatua & Ket \\
\hline $\mathrm{P}$ & Perbuatan & Pelaku & $\mathrm{O}$ & Tempat \\
\hline \multicolumn{5}{c}{} \\
\hline
\end{tabular}

Berdasarkan analisis data di atas, dinyatakan bahwa anjo merupakan pronomina penunjuk yang menunjang fungsi objek dan mengisi peran penderita.

15) Na anjo koncina kamaraka kuboliki i lalanna pattia. (cerita 12, paragraf 18) 'Sedang kunci kamar itu saya simpan di dalam peti.'

\begin{tabular}{ccccc}
\hline No Data & \multicolumn{3}{c}{ Kalimat } \\
\hline (5:) 8 & $\begin{array}{c}\text { na anjo } \\
\text { koncina } \\
\text { kamarak }\end{array}$ & $k u$ & Boliki & I lalanna pattia \\
\hline $\mathrm{F}$ & $\mathrm{O}$ & $\mathrm{S}$ & $\mathrm{P}$ & Ket \\
\hline $\mathrm{P}$ & Alat & Pelaku & Perbuatan & Keberadaan \\
\hline
\end{tabular}

Berdasarkan analisis data di atas, dinyatakan bahwa anjo merupakan pronomina penunjuk yang menunjang fungsi objek dan mengisi peran alat. 
c. Fungsi dan Peran Pronomina Penunjuk Bentuk Lain: Antu

Fungsi dan peran pronomina penunjuk antu pada teks cerita rakyat Makassar dapat ditunjukkan oleh data berikut:

1) Ammakku antu, manna tedong, manna olok-olok ka iami ampakniaki liserek matangku. (cerita 1, paragraf 18)

'Ibuku itu, biarpun kerbau, biarpun ia binatang tetapi dialah yang menyebabkan kelahiranku.'

\begin{tabular}{cccc}
\hline No Data & \multicolumn{3}{c}{ Kalimat } \\
\hline (1:18) 13 & $\begin{array}{c}\text { Ammakku } \\
\text { antu, manna } \\
\text { tedong manna } \\
\text { olok-olok }\end{array}$ & Ka iami ampakniki & Liserek matangku \\
\hline $\mathrm{F}$ & $\mathrm{S}$ & $\mathrm{P}$ & $\mathrm{O}$ \\
\hline $\mathrm{P}$ & Pelaku & Perbuatan & Dikenal \\
\hline
\end{tabular}

Berdasarkan analisis data di atas, dinyatakan bahwa antu merupakan pronomina penunjuk yang menunjang fungsi subjek dan mengisi peran pelaku.

2) "Punna nutakbangi antu buloa taena nakkulle nubesok naung, passanngalinna nubesok naikpi ri cappakna." (cerita 2, paragraf 18)

"Kalau engkau telah menebang kayu bambu itu, janganlah engkau tarik melalui pangkalnya melainkan tariklah melalui ujungnya."

\begin{tabular}{cccccc}
\hline No. Data & \multicolumn{4}{c}{ Kalimat } \\
\hline$(2: 18) 3$ & punna & $n u$ & takbangi & $\begin{array}{c}\text { Antu } \\
\text { buloa }\end{array}$ & $\begin{array}{c}\text { Taena nakkulle } \\
\text { nubesok } \\
\text { naung,passangalinna } \\
\text { nubesok naikpi ri } \\
\text { cappakna }\end{array}$ \\
\hline $\mathrm{F}$ & & & & & Ket. \\
\hline $\mathrm{P}$ & - & $\mathrm{S}$ & $\mathrm{P}$ & $\mathrm{O}$ & Cara \\
\hline
\end{tabular}

Berdasarkan analisis data di atas, dinyatakan bahwa antu merupakan pronomina penunjuk yang menunjang fungsi objek dan mengisi peran penderita.

\section{Deskripsi Fungsi dan Peran Kana Passambe Tampak 'Pronomina Tempat'}

Hasil analisis fungsi dan peran kana passambe tampak 'pronomina tempat' pada teks cerita rakyat Makassar adalah sebagai berikut.

a. Fungsi dan Peran Pronomina Tempat: Anjoreng

Fungsi dan peran pronomina tempat anjoreng pada teks cerita rakyat Makassar dapat ditunjukkan oleh data berikut:

1) Tuli i lalanna anjoreng anjo tedonga ammantang. (cerita 1, paragraf 1)

'Kerbau itu selalu tinggal di dalam hutan tadi.' 


\begin{tabular}{clll}
\hline No. Data & & Kalimat & \\
\hline$(1: 1) 3$ & Tuli I lalanna anjoreng & Anjo tedonga & Ammantang \\
\hline $\mathrm{F}$ & Ket.Tempat & $\mathrm{S}$ & $\mathrm{P}$ \\
\hline $\mathrm{P}$ & Tempat & Pelaku & Perbuatan \\
\hline
\end{tabular}

Berdasarkan analisis data di atas, dinyatakan bahwa anjoreng merupakan pronomina tempat yang mengisi fungsi keterangan tempat dan peran tempat.

2) Tasallo-salloai anjoreng niak tommi battu pung Tedong, ka battumi seng napakboyang kanre siagang jeknek inung anakna. (cerita 1, paragraf 10)

'Setelah beberapa lama berada di situ tiba-tiba datanglah kerbau itu, ia baru saja kembali mencari makanan dan minuman untuk anak-anaknya.'

\begin{tabular}{|c|c|c|c|c|c|}
\hline No. Data & & & Kalimat & & \\
\hline$(1: 10) 5$ & $\begin{array}{c}\text { Tasallo-salloai } \\
\text { nujerong niak } \\
\text { tommi battu }\end{array}$ & Pung Tedong & $\begin{array}{c}\text { Ka battumi seng } \\
\text { napakboyang }\end{array}$ & $\begin{array}{l}\text { Kanre siagang } \\
\text { jeknek inung }\end{array}$ & anakna \\
\hline $\mathrm{F}$ & Ket.Tempat & $S$ & $\mathrm{P}$ & $\mathrm{O}$ & Pel \\
\hline $\mathrm{P}$ & Tempat & Pelaku & Perbuatan & Pengalam & Penerima \\
\hline
\end{tabular}

Berdasarkan analisis data di atas, dinyatakan bahwa anjoreng merupakan pronomina tempat yang mengisi fungsi keterangan tempat dan peran tempat.

b. Fungsi dan Peran Pronomina Tempat: Anrinni

Fungsi dan peran pronomina tempat anrinni pada teks cerita rakyat Makassar dapat ditunjukkan oleh data berikut:

1) "E, I Taruk Mallintotokeng mae-mae saiko anrinni ri ampikku, niak erok kupauangko." (cerita 4, paragraf 2)

'Kemarilah engkau bersama dengan suamimu, saya ingin menyampaikan sesuatu padamu dan suamimu.'

\begin{tabular}{cccccc}
\hline No.Data & \multicolumn{5}{c}{ kalimat } \\
\hline (4:2) 5 & $\begin{array}{c}\text { E.T Taruk } \\
\text { Mallintotokeng }\end{array}$ & $\begin{array}{c}\text { Mae-mae } \\
\text { Saiko }\end{array}$ & $\begin{array}{c}\text { Anrinni ri } \\
\text { Ampik }\end{array}$ & Ku & $\begin{array}{c}\text { Niak erok } \\
\text { kupauangko }\end{array}$ \\
\hline $\mathrm{F}$ & $\mathrm{S}$ & $\mathrm{P}$ & Ket. Tempat & $\mathrm{O}$ & Ket. \\
\hline $\mathrm{P}$ & Penerima & Perbuatan & Keberadaan & Pelaku & Peserta \\
\hline
\end{tabular}

Berdasarkan analisis data di atas, dinyatakan bahwa anrinni merupakan pronomina tempat yang mengisi fungsi keterangan tempat dan peran keberadaan.

2) "Naung mako pale mae anrinni ri birinna binangaya." (cerita 6, paragraf 2)

"Turunlah kamu di sini ke tepi sungai."

\begin{tabular}{cccclc}
\hline No.Data & \multicolumn{2}{c}{ Kalimat } & & \\
\hline$(2: 18) 3$ & punna & nu & takbangi & antu \\
& & buloa & $\begin{array}{l}\text { Taena nakkulle nu } \\
\text { besok } \\
\text { passangalinna naung, } \\
\end{array}$ \\
& & & & $\begin{array}{l}\text { nubesok naikpi ri } \\
\text { caappakna }\end{array}$ \\
\hline $\mathrm{F}$ & & & & \multicolumn{2}{c}{ Ket } \\
\hline
\end{tabular}




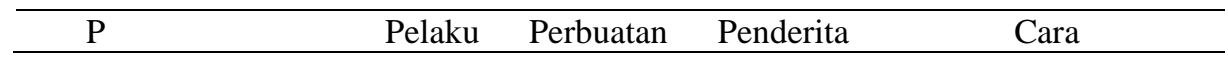

Berdasarkan analisis data di atas, dinyatakan bahwa anrinni merupakan pronomina tempat yang mengisi fungsi keterangan tempat dan mengisi peran keberadaan.

3) Niakkak anrinni mae. (cerita 14, paragraf 10)

'Saya sudah ada di sini.'

\begin{tabular}{cccc}
\hline No. Data & \multicolumn{3}{c}{ Kalimat } \\
\hline$(14: 10) 4$ & niak & ak & Anrinni mae \\
\hline $\mathrm{F}$ & $\mathrm{P}$ & $\mathrm{S}$ & Ket. Tempat \\
\hline $\mathrm{P}$ & Keadaan & Pelaku & Keberadaan \\
\hline
\end{tabular}

Berdasarkan analisis data tersebut, dinyatakan bahwa anrinni merupakan pronomina tempat yang mengisi fungsi keterangan tempat dan mengisi peran keberadaan.

c. Fungsi dan Peran Pronomina Tempat Bentuk Lain: Antureng

Fungsi dan peran pronomina tempat antureng pada teks cerita rakyat Makassar dapat ditunjukkan oleh data berikut:

1) “Apa antu nugaukang i rawa antureng sarikbattang?." (cerita 6, paragraf 10)

"Apa gerangan yang kamu tunggu di dalam jurang itu."

\begin{tabular}{ccccc}
\hline No. Data & \multicolumn{3}{c}{ Kalimat } \\
\hline$(6: 10) 1$ & $\begin{array}{c}\text { apa antu } \\
n u\end{array}$ & Gaukang & I rawa antureng & Sarikbattang \\
& $\mathrm{S}$ & $\mathrm{P}$ & Ket.Tempat & Pel. \\
\hline $\mathrm{F}$ & Pelaku & Perbuatan & Keberadaan & Peserta \\
\hline
\end{tabular}

Berdasarkan analisis data di atas, dinyatakan bahwa antureng merupakan pronomina tempat yang mengisi fungsi keterangan tempat dan peran keberadaan.

\section{Kesimpulan}

Berdasarkan hasil penelitian diperoleh tiga simpulan: (1.) Fungsi dan peran kana passambe kale 'pronomina persona' yang terdiri atas pronomina persona pertama, kedua, dan ketiga (tunggal dan jamak) pada teks cerita rakyat Makassar ditemukan dua fungsi, yakni fungsi sebagai objek dan subjek beserta tiga peran, yakni peran penderita, pelaku, dan penerima. Lebih lanjut, fungsi dan peran tersebut dirincikan sebagai berikut: mengisi fungsi objek dan peran penderita, fungsi subjek dan peran pelaku, fungsi objek dan peran penerima, fungsi subjek dan peran penderita, serta fungsi subjek dan peran penerima. (2.) Fungsi dan peran kana passambe panjojjok 'pronomina penunjuk' pada teks cerita rakyat Makassar ditemukan tiga fungsi, yakni fungsi atribut subjek, fungsi atribut objek, dan fungsi keterangan beserta delapan peran, yakni peran pelaku, 
pengalam, peserta, alat, tempat, waktu, penerima, dan penderita. Yang membedakan kana passambe kale 'pronomina persona' dengan kana passambe panjojjok 'pronomina penunjuk' adalah pronomina penunjuk hanya berfungsi sebagai atribut dari fungsi utama. Dalam artian, walaupun pronomina penunjuk tersebut tidak ada atau dihilangkan, fungsi utama dari kata yang ditunjang dapat tetap berdiri sebagai satu kesatuan yang utuh. Lebih lanjut, fungsi dan peran tersebut dirincikan sebagai berikut: fungsi atribut subjek dan peran pelaku, fungsi atribut subjek dan peran pengalam, fungsi atribut objek dan peran peserta, fungsi atribut objek dan peran alat, fungsi keterangan dan peran tempat, fungsi keterangan dan peran waktu, fungsi atribut subjek dan peran penerima, serta fungsi atribut objek dan peran penderita. (3.) Fungsi dan peran kana passambe tampak 'pronomina tempat' pada teks cerita rakyat Makassar hanya ditemukan satu fungsi, yakni fungsi keterangan beserta dua peran, yakni peran tempat dan keberadaan. Lebih lanjut, fungsi dan peran tersebut dirincikan sebagai berikut: mengisi fungsi keterangan dan peran tempat serta mengisi fungsi keterangan dan peran keberadaan.

\section{BIBLIOGRAFI}

Agustina, Diah. (2013). Aspek Budaya Dan Religi Dalam Cerita Rakyat Candi Cetho Di Kecamatan Jenawi Kabupaten Karanganyar Dan Fungsinya Bagi Masyarakat: Tinjauan Resepsi Sastra Dan Implementasinya Sebagai Bahan Ajar Sastra Indonesia Di SMA. Universitas Muhammadiyah Surakarta. Google Scholar

Asmara, Rangga. (2016). Strategi kebahasaan Presiden Jokowi dalam menanamkan ideologi dan manifesto pemerintahan. LITERA, 15(2), 379-388. Google Scholar

Badara, Aris. (2014). Analisis wacana: Teori, metode, dan penerapannya pada wacana media. Prenada Media. Google Scholar

Cipta, Rineka, \& Arkanleema, P. T. Sygma Examedia. (2013). Achmad, dan Alek Abdullah. 2013. Linguistik Umum. Jakarta: Erlangga. Annisaa Fuadillah Ramadhana. 2014. "Satuan Lingual yang Mengandung Pronomina Persona Ketiga pada TTA yang Mengandung Etika Berbahasa". Tesis. Universitas Muhammadiyah Surakarta. Asyari \&. Journal. Universiti Utara Malaysia, 95, 104. Google Scholar

Daeng, Kembong. (2016). Pappilajarang Basa siagang Sasetera Mangkasarak SMP/MTS VII. Makassar. UD. Google Scholar

Devianty, Rina. (2017). Bahasa sebagai cermin kebudayaan. Jurnal Tarbiyah, 24(2). Google Scholar

Pratama, Rafhiqi. (2017). Analisis Pemakaian Bentuk-Bentuk Pronomina Persona Dalam Novel Tahajud Cinta Di Kota New York Karya Arumi E. Aksara: Jurnal Ilmiah Pendidikan Bahasa Dan Sastra Indonesia, 1(1), 33-42. Google Scholar

Rachman, Abdul. (2016). Pola Iringan Engkel Instrumen Cak Dan Cuk Dalam Lagu 
Riyatni Imas Garina

Langgam Jawa Pada Orkes Keroncong Sekar Domas Di Semarang. Jurnal Konferensi Internasional VI Bahasa, Sastra Dan Budaya Daerah Indonesia, 7(9), 1-7. Google Scholar

Salamah, Siti. (2015). Studi Ringkas Pemerolehan Bahasa Pada Anak. PBSI FKIP Universitas Ahmad Dahlan Yogyakarta. Bahastra, 33(2), 73-82. Google Scholar

Sarisati, Sekar Puspa. (2017). Pembelajaran Memproduksi Teks Drama Dengan Menggunakan Model Experiental Learning Pada Siswa Kelas Xi Sman 20 Bandung Tahun Pelajaran 2016/2017. Fkip Unpas. Google Scholar

Sw, Siti Wahyuni. (2019). Pronomina Persona Dalam Bahasa Sasak Dialek MenuMeni. Universitas Gadjah Mada. Google Scholar

Widianto, Eko. (2018). Pemertahanan Bahasa Daerah melalui Pembelajaran dan Kegiatan di Sekolah. KREDO: Jurnal Ilmiah Bahasa Dan Sastra, 1(2), 1-13. Google Scholar

Copyright holder :

Riyatni Imas Garina (2021)

First publication right :

Jurnal Syntax Idea

This article is licensed under:

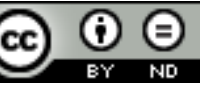

